Article

\title{
Coal-Mining Tailings as a Pozzolanic Material in Cements Industry
}

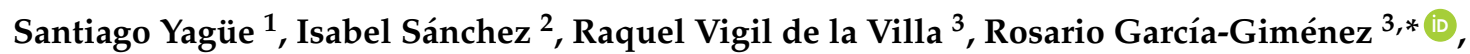 \\ Antonio Zapardiel ${ }^{2}$ and Moisés Frías 4 (D) \\ 1 ETS Ingenieros Industriales, Universidad Nacional de Educación a Distancia (UNED), 28040 Madrid, Spain; \\ santiagooyg@hotmail.com \\ 2 Facultad de Ciencias, Universidad Nacional de Educación a Distancia (UNED), 28040 Madrid, Spain; \\ isa.svigil@gmail.com (I.S.); azapardiel@ccia.uned.es (A.Z.) \\ 3 Dpto de Geología y Geoquímica, Unidad Asociada CSIC-UAM, Universidad Autónoma de Madrid (UAM), \\ 28049 Madrid, Spain; raquel.vigil@uam.es \\ 4 Eduardo Torroja Institute (CSIC), Spanish National Research Council, 28033 Madrid, Spain; \\ mfrias@ietcc.csic.es \\ * Correspondence: rosario.garcia@uam.es
}

Received: 20 December 2017; Accepted: 25 January 2018; Published: 29 January 2018

\begin{abstract}
The generation of enormous volumes of mine-tailing waste is standard practice in the mining industry. Large quantities of these tailings are also sources of kaolinite-rich materials that accumulate in slag heaps, causing significant environmental degradation and visual impacts on the landscape. The consequences of coal refuse dumped in slagheaps calls for the study of eco-innovative solutions and the assessment of waste types. Moreover, the environmental benefits of reusing large amounts of contaminated waste are also evident. Hence, the objective of this investigation is to expand current knowledge of new siliceous-aluminium minerals and their pozzolanic activity. Four raw tailing samples are characterized to determine their chemical (by ICP/MS analysis), morphological (by SEM/EDX analysis), and mineralogical (by XRD analysis) compositions prior to their thermal activation that transforms the inert wastes at various temperatures into materials with cementitious properties. The results of XRD analysis following activation confirmed that the kaolinite content is fully transformed into metakaolinite. The coal refuse samples presented sufficiently reliable levels of pozzolanic activity for use as additives in industrial cements.
\end{abstract}

Keywords: coal-mining tailings; thermally activated tailings; cement; pozzolan; mineralogy; metakaolinite

\section{Introduction}

Material and energetic recycling of raw materials found in by-products is a priority line of action in industrial sectors. The search for strategies that promote large-scale rotation of industrial waste in productive cycles has therefore evolved into a central economic activity. The examination of these strategies demands exhaustive scientific-technical knowledge of current research projects, bringing benefit to potential applications that employ these waste products.

Prolific research and scientific-technical contributions underpin the use of industrial wastes and byproducts in the manufacturing processes of cement and construction materials, while competitive designs incorporated in manufacturing processes remain mainstream research topics in the industry. Hence, there is a need to diversify the sources and the supply of pozzolanic mineral additives for use in the manufacture of cements and related materials. The evaluation of industrial wastes and byproducts form the main plank of these investigations, thanks to which pozzolanic fractions are now specified in a range of cement standards [1-5]. Thus, a central research topic, core to numerous 
investigations [6-12], concerns the activation of clayey materials, principally in the form of kaolinite (K), from which metakaolin (MK) is generated by the controlled activation of natural kaolinite.

Environmental impacts and human health problems in coal-mining environments have also been extensively researched over many years [13-18]. There is a long list of environmental hazards associated with coal mining: visual impacts on the landscape, air, and even noise pollution, soil erosion, soil and sediment contamination, slag heaps and slag-heap fires, subsidence, surface and groundwater pollution, and a general degradation of local biodiversity [19-21]. Extraction and dumping of voluminous amounts of discarded mine tailings provoke additional environmental problems. The disposal of coal-mine tailings is also associated with specific hazards: atmospheric dispersion of particles, spontaneous combustion of slag heaps, landslides, contaminant mobilization, leaching of elements, and formation of acid drainage caused by weathering and/or oxidation processes. Despite the significant environmental impact of mine tailings that degrade the environment, the large volumes of tailings that the mining industry generates are also significant sources of kaolinite-rich wastes. The application of mine tailings, up to now, has been investigated to evaluate the effect of flay ash as amendment on the compression in these materials [22] in cemented paste backfill with substitutions of Portland cement by sulphide tailings [23] and cement-stabilized granite mill tailings used as a subbase material in highway construction [24], among others.

Coal refuse is heaped in slag heaps because high-quality coal will be degraded if mixed with metallic minerals and a series of incombustible inorganic impurities found in the tailings. The impact of coal refuse calls for the study of eco-innovative solutions for the assessment of waste types [25], with a view to the systematic recovery of these mineral and energetic resources at the lowest possible environmental costs.

In accordance with the specifications sheet prepared by Center of Studies and Experimentation of Public Works (CEDEX) [26], mine-tailings refer to the excess waste after having extracted the coal, sourced from the exploitation of open-cast and underground mines (10\% of the total) and coal-washing processes $(90 \%)$. The coal tailings containing an accumulation of materials that provoke significant environmental contamination mines undergo natural weathering in open-air storage for lengthy periods [27].

Weathering processes such as washing in water and spontaneous combustion of slag heaps also pose significant environmental problems. Mineral composition (especially pyrite), volatile matter, types of organic matter, direct contact with water (wetting), and storage times are also important factors [28-32]. Poor compaction facilitates the penetration of both air and water, thereby increasing the risks of spontaneous combustion. Spanish legislation on environmental matters and laws on the evaluation of environmental impacts require all mining exploitations at the end of their productive life to submit and to put into action a Plan for the Abandonment and Closure of the Mine and for byproduct recycling.

Hence, the objective of this investigation is to expand current knowledge of new siliceous-aluminium minerals and their pozzolanic activity as part of a preliminary study on their use as pozzolanic additives in the manufacture of cement systems, at the lowest possible cost, from the waste from coal mining.

\section{Materials and Methods}

\subsection{Materials}

The study area, located in El Bierzo County (Figure 1), in the province of Leon (Spain), is a coalfield of $310 \mathrm{~km}^{2}$, in an area that has been exploited since the mid-19th century [27]. The mineralogy of the coal samples is composed mainly of mica/illite, with quartz, kaolinite, and pyrophyllite as additional major constituents. In some areas, carbonate bags appear that interrupt the coal series [33]. Four types of samples were selected from the mines of the Sociedad Anónima Huellera Vasco-Leonesa, Santa Lucía, León, Spain (Figure 2a). The first sample was mining (coal) refuse (overburden and 
waste rock, raw tailings), extracted at low levels, comprising top soil and overburden, waste-rock, and low-grade minerals. High volumes of these inert materials are found piled in slag heaps in the area around the coalfield (Figure 2b). The other three samples ("tailings") consisted of coal refuse from coal-flotation treatments that extract the coal from the crushed fines. The three samples were graded by particle size: coarse-grade $(12.00$ to $0.50 \mathrm{~mm})$, fine-grade $(0.50$ to $0.05 \mathrm{~mm})$, and very fine-grade samples $(<0.05 \mathrm{~mm})$ of coal waste.

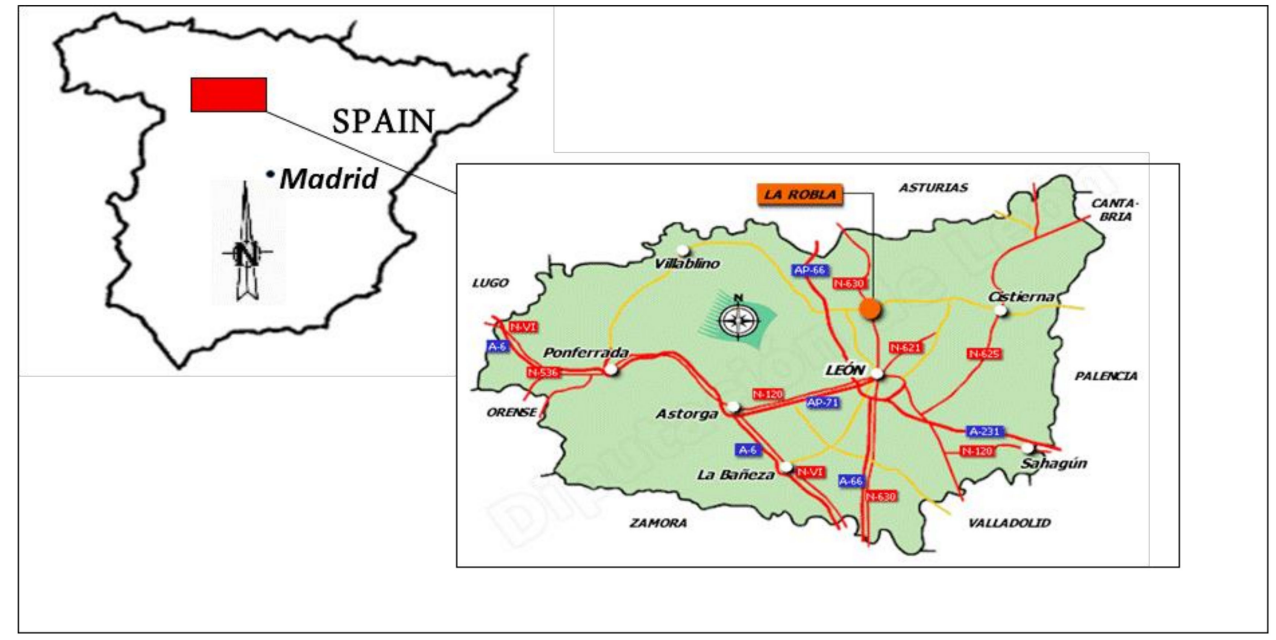

Figure 1. Location map of the study area.

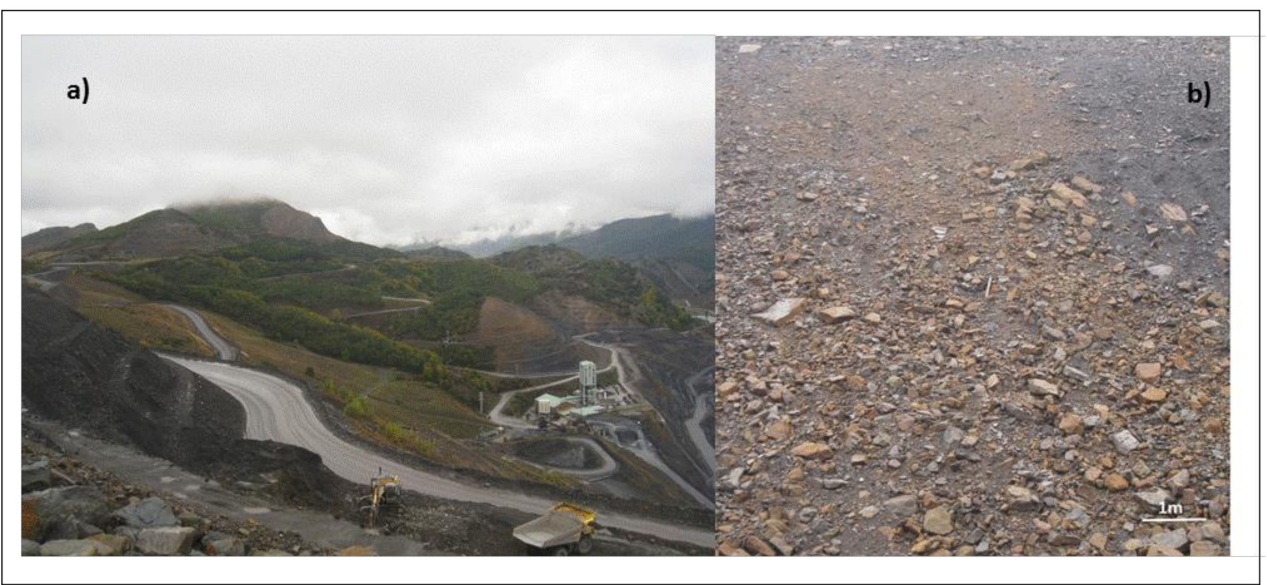

Figure 2. (a) General view of the mining exploitation of Santa Lucía (León, Spain). (b) Detail of material from a slap heap.

\subsection{Methods}

The four samples were characterized to determine their chemical composition (most abundant elements, trace elements, total organic coal content, sulphurs, and loss on ignition) and morphological and mineralogical traits (total and clayey minerals). All samples were ground in agate mortar for homogenization. The aforementioned samples were subjected to different thermal activation conditions (heating from $500{ }^{\circ} \mathrm{C}$ to $900{ }^{\circ} \mathrm{C}$, over $2 \mathrm{~h}$ in an electric furnace) for the transformation of inert waste into materials with cementitious properties.

Different techniques were used.

(1) The chemical characterization was performed with Inductively Coupled Plasma Mass Spectrometry (ICP/MS) (Perkin Elmer, Waltham, MA, USA) prior to having immersed the 
sample in an acidic solution (ICP-MS Elan 6000 Perkin Elmer Sciex with an AS91 autosampler, Perkin Elmer, Waltham, MA, USA). The content of organic coal in the solid samples was determined by the difference between the total content of coal and inorganic coal, using a total organic carbon analyzer, the Shimadzu (Total Organic Carbon Analyzer) TOC-5000 A (Shimadzu, Kyoto, Japan), with a module for solid samples (Solid Sample Module) SSM-5000 A (Shimadzu, Kyoto, Japan).

(2) The mineralogical composition was determined by X-ray diffraction (XRD, Siemens, Munich, Germany) with the powder method and the $<2 \mu \mathrm{m}$ fraction with the oriented aggregate method; in both cases completing the diffractograms in a Siemens diffractometer D-5000 fitted with a $\mathrm{Cu}$ anode [34]. The characterization of the bulk samples was performed with the Rietveld method [35].

(3) The scanning electron microscopy (SEM) morphological observations and the energy dispersive X-ray (EDX) microanalysis were performed with an FEI electronic microscope equipped with an energy dispersive X-ray spectrometer (source of W, DX4i analyzer and $\mathrm{Si} / \mathrm{Li}$ detector).

The determination of pozzolanic activity sheds light on the pozzolanic activity of pozzolan/hydroxide calcium (lime) systems using the solid waste after having applied an accelerated chemical method [2]. After 1, 7, and 28 days of reaction, the waste product was washed with acetone and then dried in an electric furnace at $60^{\circ} \mathrm{C}$, over $24 \mathrm{~h}$, ending the pozzolanic reaction. The content of fixed lime was measured as the difference between the concentration of $\mathrm{CaO}(\mathrm{mmol} / \mathrm{L})$ in the initial saturated-lime solution $(17.68 \mathrm{mmol} / \mathrm{L})$ and the content of the same compound in the solution after fixed intervals of time.

\section{Results and Discussion}

\subsection{Raw Materials}

The mineralogical characterization of the four raw tailings samples by XRD (Figure 3) identified a major presence of phyllosilicates (mica and kaolinite) accompanied by quartz, calcite, dolomite, and feldspars. Given that the phyllosilicates are responsible for the pozzolanic activity, a decisive property in the use of pozzolan materials is found in the very fine-grade samples with the highest content of micas and kaolinite $(48 \%)$, as opposed to the coal refuse with a lower content of those minerals $(24 \%)$. The other two tailing samples had intermediate values in relation to the rest of the mineral components. Trace concentrations of feldspars were found in all samples with variable quantities of calcite, dolomite, and quartz, depending on each particular one (Table 1). Silicate and aluminium-silicate minerals were the dominant elements in all four samples. The granulometry of the samples is given in Table 2, and it can be deduced that the coal refuse and very fine tailings samples are those with the finest granulometry including clay and silt.

Table 1. X-ray diffraction (XRD) mineralogical analysis of the raw tailings samples.

\begin{tabular}{ccccc}
\hline \multirow{2}{*}{ Mineral (\%) } & \multicolumn{3}{c}{ Tailings } & \multirow{2}{*}{ Coal Refuse } \\
\cline { 2 - 4 } & Very fine & Fine & Coarse & \\
\hline Mica & 30 & 26 & 28 & 20 \\
Kaolinite & 18 & 6 & 10 & 4 \\
Quartz & 5 & 13 & 10 & 34 \\
Feldspars & Traces & Traces & Traces & Traces \\
Calcite & 25 & 30 & 30 & 23 \\
Dolomite & 15 & 10 & 10 & 7 \\
Amorphous material & 7 & 15 & 12 & 12 \\
R & 26.0 & 16.4 & 19.6 & 17.3 \\
Global chi ${ }^{2}$ & 8.6 & 5.4 & 8.3 & 7.0 \\
\hline
\end{tabular}


Table 2. Granulomety of the raw tailings samples.

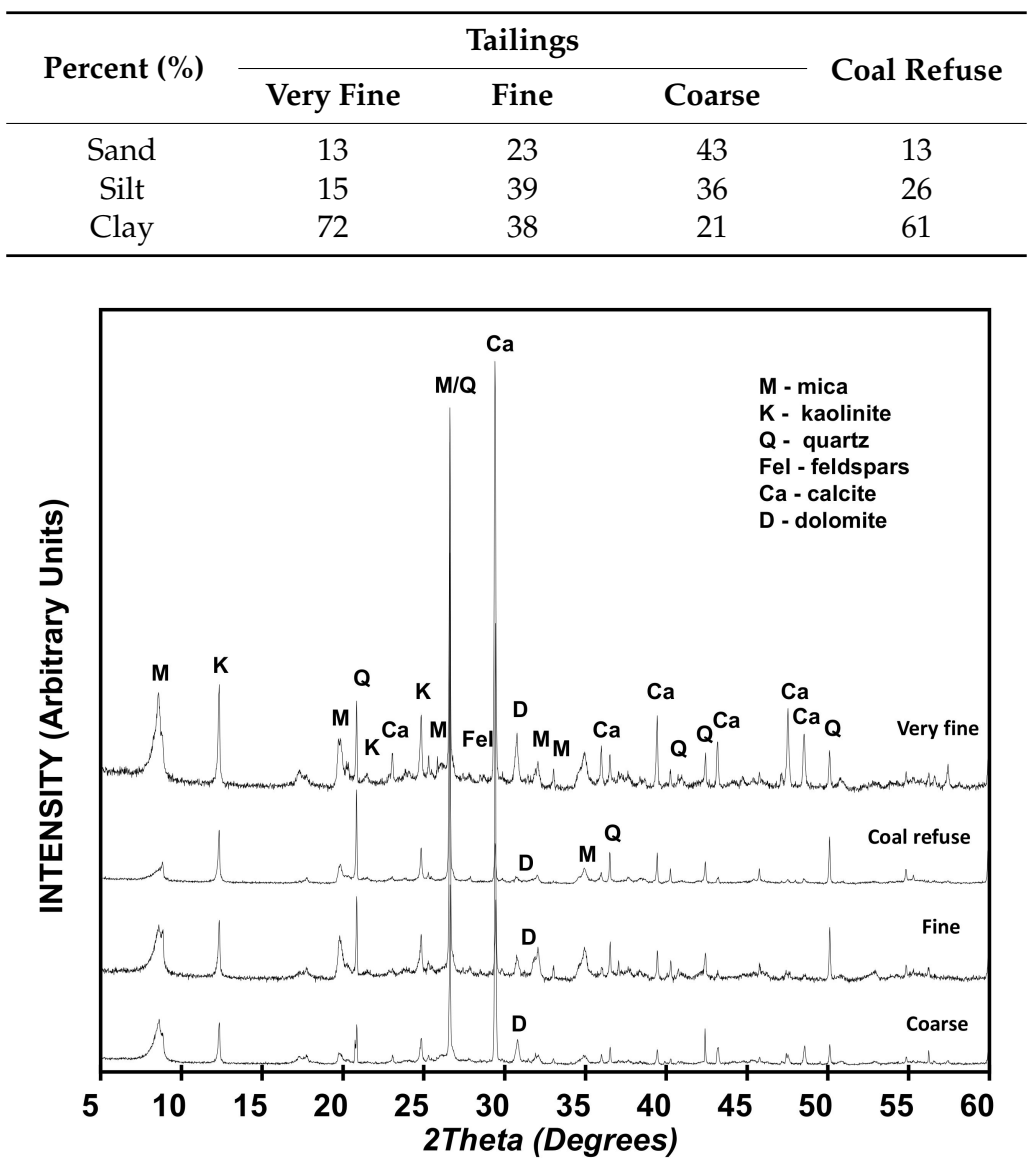

Figure 3. Diffraction spectra of the raw tailings samples.

SEM/EDX analysis of the very fine-grade raw tailings sample indicated the presence of variable sizes of aggregates (Figure 4A). The irregular aggregate surfaces (Figure 4B) are filled with pores and cracks that assist their disaggregation. Idiomorphic pyrite crystals were identified in the gaps of the phyllosilicate layers, in dispersed and concentrated forms forming clusters (Figure 4C). The aggregates consisted of calcite, quartz, and phyllosilicates (Figure 4D and Table 3) [17,34]. The grain sizes of the fine tailings were of greater uniformity (Figure $4 \mathrm{E}$ ) and of larger size than those of the very fine grade sample, with phyllosilicate and quartz aggregates and pyrite crystals in the gaps between the layers of phyllosilicate (Figure 4F). The aggregates were, in general, of a compact appearance.

Table 3. Energy dispersive X-ray (EDX) chemical analysis: very fine-grade raw tailings sample.

\begin{tabular}{ccccc}
\hline Oxides (\%) & Phyllosilicate & Pyrite & Quartz & Calcite \\
\hline $\mathrm{Na}_{2} \mathrm{O}$ & $0.83 \pm 0.22$ & n.d. & n.d. & n.d. \\
$\mathrm{MgO}$ & $0.98 \pm 0.43$ & n.d. & n.d. & n.d. \\
$\mathrm{Al}_{2} \mathrm{O}_{3}$ & $36.31 \pm 1.39$ & n.d. & n.d. & n.d. \\
$\mathrm{SiO}_{2}$ & $54.45 \pm 1.63$ & n.d. & 100 & n.d. \\
$\mathrm{S}^{2-}$ & n.d. & 72.03 & n.d. & n.d. \\
$\mathrm{Fe}^{2+}$ & n.d. & 27.97 & n.d. & n.d. \\
$\mathrm{K}_{2} \mathrm{O}$ & $4.43 \pm 1.28$ & n.d. & n.d. & n.d. \\
$\mathrm{CaO}$ & $0.33 \pm 0.12$ & n.d. & n.d. & 100 \\
$\mathrm{TiO}_{2}$ & $1.43 \pm 0.98$ & n.d. & n.d. & n.d. \\
$\mathrm{Fe}_{2} \mathrm{O}_{3}$ & $1.24 \pm 0.85$ & n.d. & n.d. & n.d. \\
\hline
\end{tabular}

n.d. $=$ not detected 

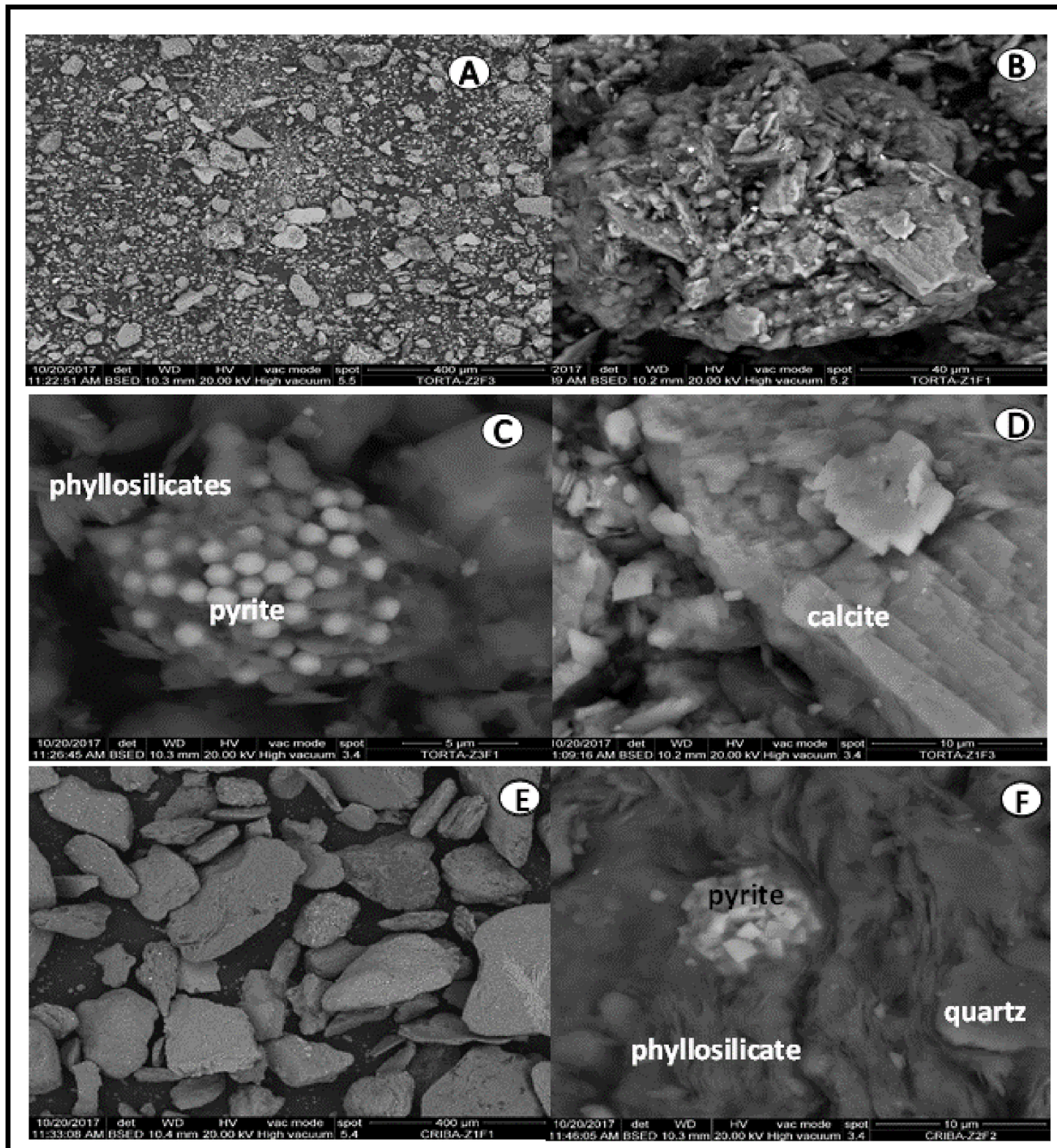

Figure 4. Scanning electron microscopy (SEM) analysis: (A) aggregates of variable size in very fine-grade raw tailings sample; (B) porous aggregates in very fine-grade sample; (C) sheets of phyllosilicates with cavities containing idiomorphic pyrite crystals in the very fine-grade sample; (D) rhombohedral exfoliation calcite crystals in very fine-grade sample; (E) homogeneous size of aggregates in fine-grade sample; (F) phyllosilicates, quartz, and pyrite crystals in fine-grade sample.

In turn, the presence of very compact aggregates in the coal-refuse samples were generally formed of phyllosilicates, calcite, and quartz (Figure 5A). Phosphates, iron, calcium, and magnesium accumulated in disordered and random concentrations mainly in the clayey aggregates (Figure 5B and Table 4). These varied concentrations occur due to the undulatory surface forms of the phyllosilicates (Figure 5C), where fractures and voids facilitate their deposition (Figure 5D). The surface cavities of the aggregates were filled with compacted organic matter, and disorderly surface deposits of pyrite crystals were noted elsewhere $[15,17]$. 


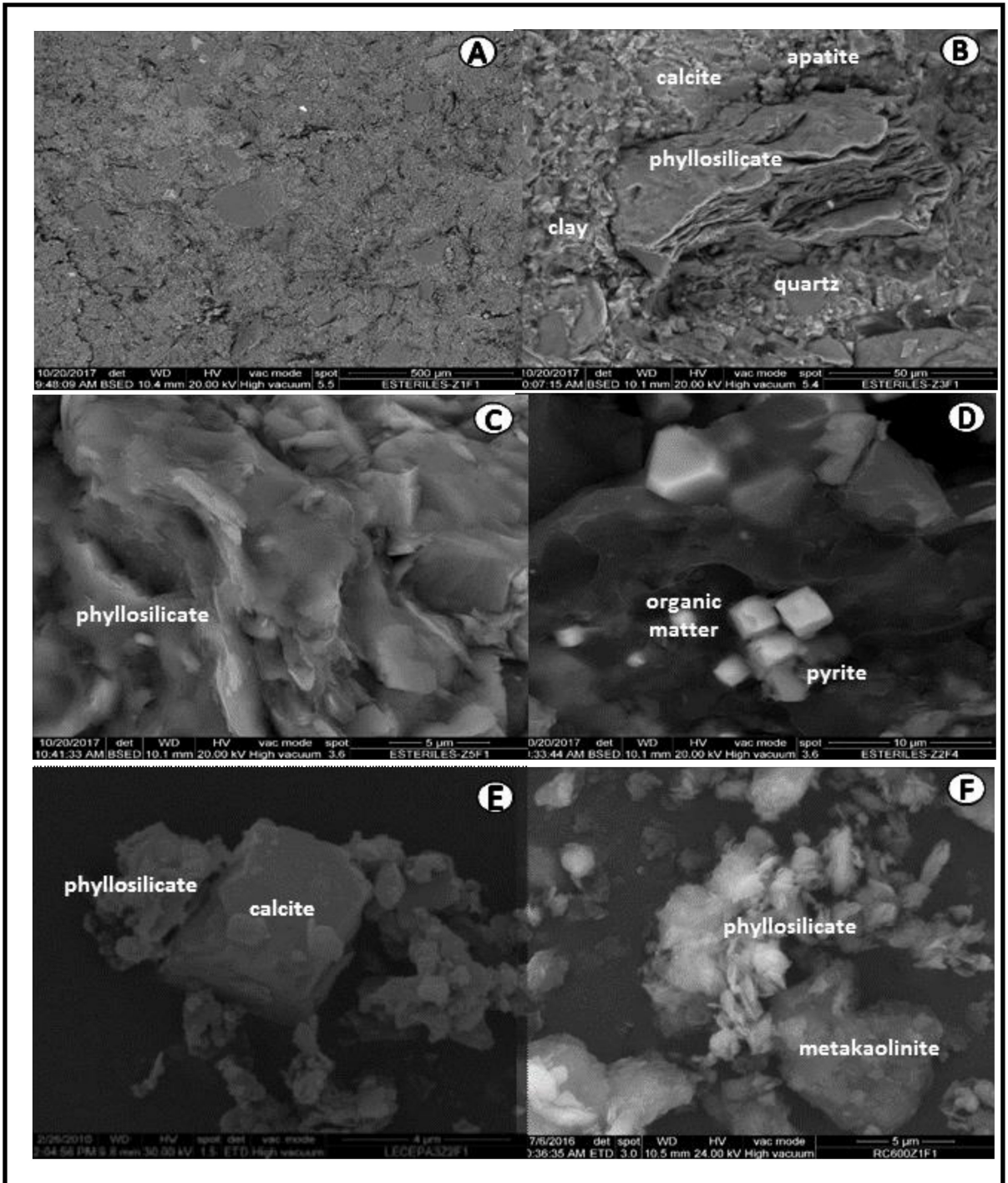

Figure 5. SEM analysis in the coal refuse sample: (A) compact aggregates; (B) detail with clay aggregates containing different ions; (C) aggregates of phyllosilicates with folded edges; (D) aggregates containing organic matter and pyrite crystals; (E) calcite and MK rhombohedrum in the coal-refuse sample thermally activated at $600^{\circ} \mathrm{C}$; (F) detail of activated phyllosilicates and MK.

Table 4. Chemical analysis by EDX of the aggregates from the coal-refuse sample.

\begin{tabular}{ccccccc}
\hline Oxides (\%) & Phyllosilicate & Clay & Apatite & Pyrite & Quartz & Calcite \\
\hline $\mathrm{Na}_{2} \mathrm{O}$ & $0.76 \pm 0.35$ & n.d. & n.d. & n.d. & n.d. & n.d. \\
$\mathrm{MgO}$ & $1.27 \pm 0.63$ & 22.12 & n.d. & n.d. & n.d. & n.d. \\
$\mathrm{Al}_{2} \mathrm{O}_{3}$ & $32.53 \pm 1.58$ & 3.27 & n.d. & n.d. & n.d. & n.d \\
$\mathrm{SiO}_{2}$ & $55.96 \pm 2.41$ & 4.83 & n.d. & n.d. & 100 & n.d. \\
$\mathrm{S}^{2-}$ & n.d. & n.d. & n.d. & 72.03 & n.d. & n.d. \\
$\mathrm{Fe}^{2+}$ & n.d. & n.d. & n.d. & 27.97 & n.d. & n.d. \\
$\mathrm{K}_{2} \mathrm{O}$ & $5.32 \pm 1.93$ & 0.71 & n.d. & n.d. & n.d. & n.d. \\
$\mathrm{CaO}$ & $1.20 \pm 0.74$ & 44.61 & 53.67 & n.d. & n.d. & 100 \\
$\mathrm{TiO}_{2}$ & $0.54 \pm 0.46$ & n.d. & n.d. & n.d. & n.d. & n.d. \\
$\mathrm{Fe}_{2} \mathrm{O}_{3}$ & $2.39 \pm 1.49$ & 24.46 & n.d. & n.d. & n.d. & n.d. \\
$\mathrm{P}_{2} \mathrm{O}_{5}$ & n.d. & n.d. & 43.33 & n.d. & n.d. & n.d. \\
\hline
\end{tabular}

n.d. $=$ not detected 
The chemical composition of the four raw tailings samples (Table 5) indicated that they were all of a silico-aluminous nature with percentages $\left(\mathrm{SiO}_{2}+\mathrm{Al}_{2} \mathrm{O}_{3}\right)$ of between $50 \%$ and $70 \%$ of the total weight. There was a practically constant presence of iron oxide in all of them, and a very variable quantity of $\mathrm{CaO}$ (the fine-grade with the highest percentage $-16.20 \%$ - and the coal refuse with the lowest-3.84\%), as well as loss on ignition (very fine-grade with the highest weight loss-26.47\%—and the mining refuse with the lowest-15.18\%). MnO was practically constant in all the samples, fluctuating between $0.87 \%$ and $0.59 \%$. The alkaline oxides $\left(\mathrm{Na}_{2} \mathrm{O}+\mathrm{K}_{2} \mathrm{O}\right)$ were approximately $2.46 \%$ in the very fine-grade samples and $2.87 \%$ in the mining refuse. Higher concentrations of $\mathrm{SO}_{3}$ were found in the fine-grade raw tailings $(0.92 \%)$, and the lowest concentrations were once again found in the coal-refuse sample $(0.27 \%)$. Finally, concentrations of $\mathrm{P}_{2} \mathrm{O}_{5}$ were at their highest in the very fine-grade samples $(0.26 \%)$ and lowest in the coal refuse $(0.13 \%)$. The very fine raw tailings had the highest content of organic carbon $(24.27 \%)$, while the lowest content was found in the coal refuse $(16.04 \%)$.

Table 5. Chemical analysis of the four raw tailings samples.

\begin{tabular}{ccccc}
\hline \multirow{2}{*}{ Oxides (\%) } & \multicolumn{3}{c}{ Tailings } & \multirow{2}{*}{ Coal Refuse } \\
\cline { 2 - 4 } & Very Fine & Fine & Coarse & \\
\hline $\mathrm{SiO}_{\mathbf{2}}$ & 32.99 & 41.35 & 43.12 & 49.79 \\
$\mathrm{Al}_{\mathbf{2}} \mathbf{O}_{3}$ & 19.90 & 9.37 & 12.16 & 21.77 \\
$\mathrm{Fe}_{\mathbf{2}} \mathbf{O}_{\mathbf{3}}$ & 4.09 & 4.13 & 4.21 & 4.07 \\
$\mathbf{M n O}$ & 0.13 & 0.11 & 0.10 & 0.08 \\
$\mathbf{M g O}$ & 0.87 & 0.65 & 0.59 & 0.64 \\
$\mathbf{C a O}$ & 11.44 & 15.21 & 16.20 & 3.84 \\
$\mathbf{N a}_{\mathbf{2}} \mathbf{O}$ & 0.35 & 0.32 & 0.25 & 0.13 \\
$\mathbf{S O}_{3}$ & 0.83 & 0.92 & 0.77 & 0.27 \\
$\mathbf{K}_{\mathbf{2}} \mathbf{O}$ & 2.11 & 2.18 & 2.27 & 2.74 \\
$\mathrm{TiO}_{\mathbf{2}}$ & 0.57 & 0.46 & 0.65 & 1.07 \\
$\mathbf{P}_{\mathbf{2}} \mathbf{O}_{\mathbf{5}}$ & 0.26 & 0.16 & 0.22 & 0.13 \\
Loss on ignition & 26.47 & 25.14 & 19.46 & 15.18 \\
$\mathbf{T O T A L}$ & 100.01 & 100.00 & 100.00 & 99.71 \\
Organic carbon & 24.27 & 21.54 & 18.14 & 16.04 \\
\hline
\end{tabular}

For a better understanding, and following Gorakhki and Bareither [22], the triangular diagram is represented, showing the affinity of the coarse and fine tailings samples and the separation of the rest of the samples (very fine tailings and coal refuse) where the concentrations of silicon and aluminium are the major (Figure 6).

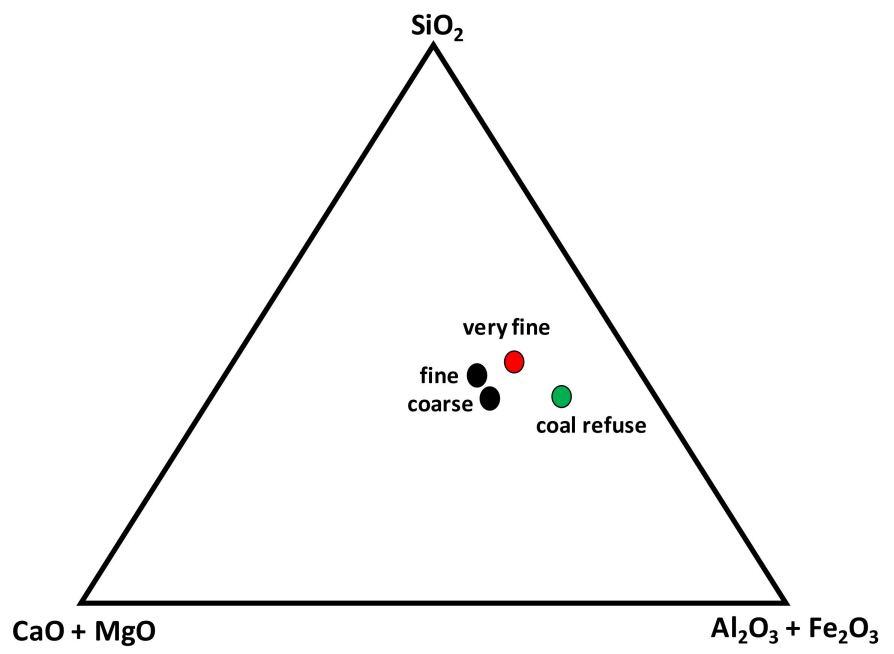

Figure 6. Triangular diagram from the mayor elements in the tailings and coal refuse. 
Trace elements of $\mathrm{Ni}, \mathrm{Cr}, \mathrm{V}, \mathrm{Zn}, \mathrm{Pb}, \mathrm{As}, \mathrm{Co}$, and Mo were found in concentrations lower than $200 \mathrm{mg} / \mathrm{L}$ (Table 6) that reportedly [36] have a direct influence on the rheological properties of the pozzolanic cements.

Table 6. Chemical analysis of minor elements in the raw tailings samples (n.d. = not detected).

\begin{tabular}{ccccc}
\hline \multirow{2}{*}{$\begin{array}{c}\text { Element } \\
(\mathbf{m g} / \mathrm{L})\end{array}$} & \multicolumn{3}{c}{ Tailings } & Coal Refuse \\
\cline { 2 - 4 } & Very fine & Fine & Coarse & \\
\hline $\mathbf{C u}$ & n.d. & n.d. & n.d. & n.d. \\
$\mathbf{N i}$ & 50 & 63 & 77 & 26 \\
$\mathbf{C r}$ & 100 & 150 & 176 & 98 \\
$\mathbf{V}$ & 88 & 103 & 133 & 112 \\
$\mathbf{Z n}$ & 10 & 18 & 30 & 32 \\
$\mathbf{P b}$ & 3 & 4 & 3 & 5 \\
$\mathbf{C d}$ & n.d. & n.d. & n.d. & n.d. \\
$\mathbf{A s}$ & 2 & 2 & 2 & 2 \\
$\mathbf{C o}$ & 11 & 15 & 12 & 8 \\
$\mathbf{M o}$ & 18 & 15 & 17 & 21 \\
\hline
\end{tabular}

The chemical analyses indicated that the most appropriate sample for use as a coal-mining pozzolan waste would be the very fine-grade raw tailings samples with a granulometry of $\leq 0.05 \mathrm{~mm}$, following flotation treatment of the tailings. Nevertheless, this product requires pre-flotation treatment after extraction, as previously mentioned, and low volumes are generated following the treatment process, in contrast with the amounts in the coal refuse.

\subsection{Thermally Activated Materials}

The raw tailings samples were calcinated within a thermal range of $500{ }^{\circ} \mathrm{C}$ to $900{ }^{\circ} \mathrm{C}$ after two hours in an electric furnace, which should transform the $\mathrm{K}$ into $\mathrm{MK}$ and simultaneously dehydroxylate the micas. The intention was to confirm this hypothesis, given that the most reactive state of the phyllosilicates occurs when the material is found in a dehydroxylated form due to loss of the hydroxyl groups by calcination [37].

With the increase of temperature, the $\mathrm{K}$ loses crystallinity as well as the micas, which becomes an increase of amorphous materials. By XRD, the mineralogical composition of the calcinated samples a different temperatures are shown in Figure 7 . In all samples, the major material at $500{ }^{\circ} \mathrm{C}$ is the mica, except in the fine sample. The same happens with calcite, which decreases when the temperature is high, presenting a similar amount in the initial stages of calcination.

The highest concentration of $\mathrm{K}$ is identified in the very fine sample. The transformation both of the kaolinite at $600{ }^{\circ} \mathrm{C}$ (into MK unidentifiable by XRD due to its amorphousness) and of the dolomite was noted, as was the disappearance of the calcite at $800{ }^{\circ} \mathrm{C}$.

On the other hand, the concentration of quartz increase in all samples with a decrease in coal refuse, compensated by the amorphous materials. Hematite increases in all raw tailing samples, except in fine sample. In addition, spinel is a new mineral that appears at $600{ }^{\circ} \mathrm{C}$ because of the thermal treatment of the aluminous minerals of the clay [12,38].

A temperature of $600{ }^{\circ} \mathrm{C}$ applied over $2 \mathrm{~h}$ was selected as the ideal temperature for thermal activation of the coal waste, thereby economizing on energy. At this temperature, all $\mathrm{K}$ is transformed into MK.

Given these results, and given the volume of waste for which no treatment is required, the coal refuse was chosen for its easy handling and provisioning, which saves the basic material. 


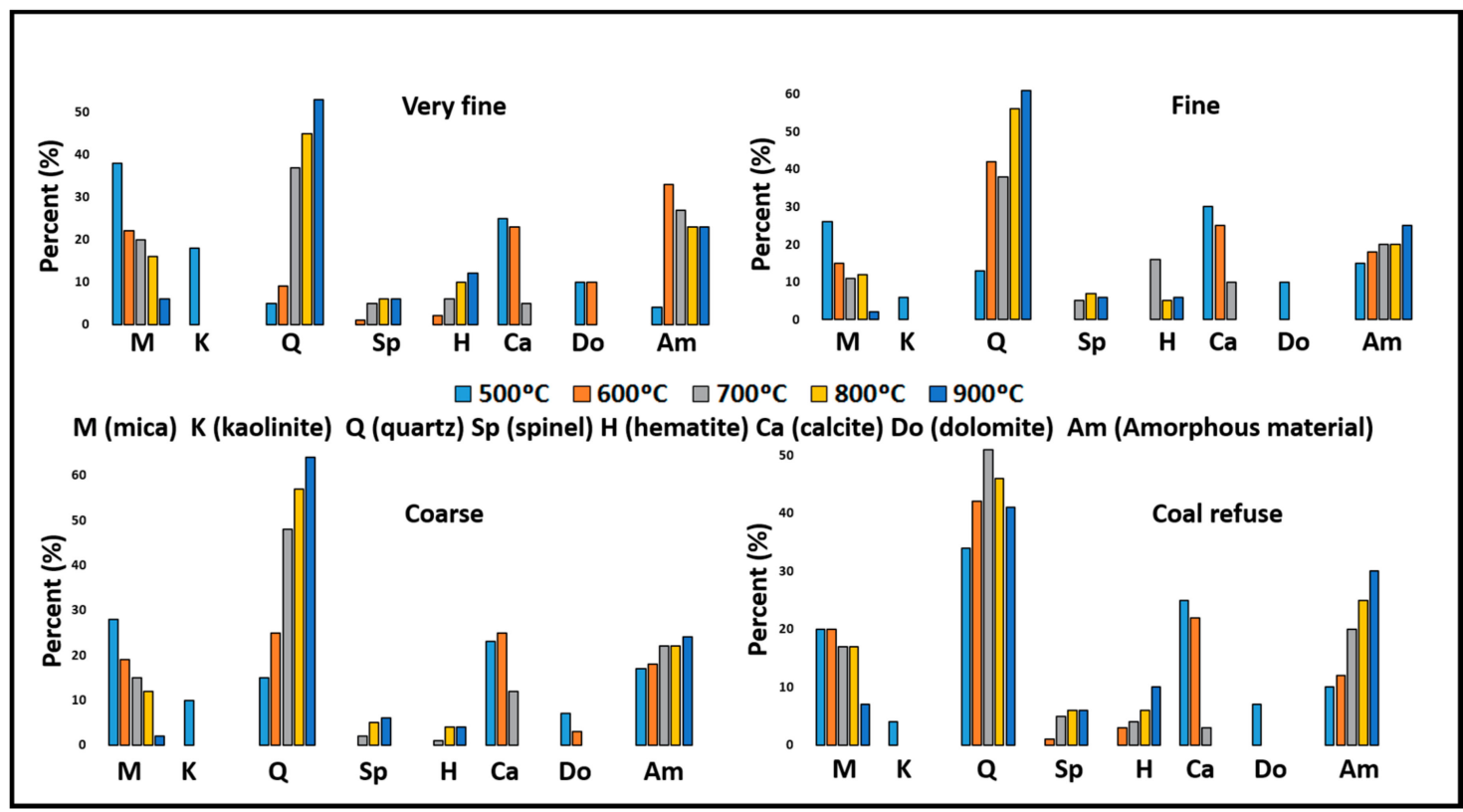

Figure 7. Mineralogical composition by XRD from the thermally activated samples between $500{ }^{\circ} \mathrm{C}$ and $900{ }^{\circ} \mathrm{C}$.

For a better certainty in the election, the coal refuse was analyzed by SEM/EDX. These observation shows the disaggregation of the aggregates due to the destruction of the organic matter. The appearance was noted of MK laminar aggregates with surface deposits of sulphur, potassium, and calcium, as well as aggregates with frayed laminates from the partial dehydroxylation of the remaining phyllosilicates (Figure 5E and Table 7).

Table 7. EDX chemical analysis of the aggregates from the thermally activated coal refuse sample at $600{ }^{\circ} \mathrm{C}$.

\begin{tabular}{ccc}
\hline Oxides (\%) & Phyllosilicate & Metakaolinite \\
\hline $\mathrm{MgO}$ & 0.97 & n.d. \\
$\mathrm{Al}_{2} \mathrm{O}_{3}$ & 26.55 & 35.62 \\
$\mathrm{SiO}_{2}$ & 61.69 & 58.58 \\
$\mathrm{SO}_{3}$ & 3.22 & 1.00 \\
$\mathrm{~K}_{2} \mathrm{O}$ & 3.10 & 2.92 \\
$\mathrm{CaO}$ & 1.41 & 1.89 \\
$\mathrm{TiO}_{2}$ & 0.88 & n.d. \\
$\mathrm{Fe}_{2} \mathrm{O}_{3}$ & 2.17 & n.d. \\
\hline
\end{tabular}

n.d. = not detected

Pozzolanic properties are the fundamental property in industrial byproducts that are to be used as an active cement additive. Figure 8 shows the graph of coal-refuse (overburden, waste rock, and occasional low-grade mineral waste) pozzolanic activity, activated at $600{ }^{\circ} \mathrm{C} / 2 \mathrm{~h}$ over 90 days of reaction time. The analytic results, expressed as percentages of fixed lime, indicate the high pozzolanic activity of the coal refuse activated at $600^{\circ} \mathrm{C}$. This value is similar than the obtained with an available commercial MK in UK. The commercial MK is mayor oxides of $\mathrm{SiO}_{2}(51.60 \%)$ and $\mathrm{Al}_{2} \mathrm{O}_{3}(41.30 \%)$, and a surface area of $15.0 \mathrm{~m}^{2} / \mathrm{g}$ [39] at all ages (except at 28 days).The mineralogical composition of commercial $\mathrm{K}$ was principally kaolinite and mica. Calcination at $600{ }^{\circ} \mathrm{C} / 2 \mathrm{~h}$ produced total dehydroxylation of the $\mathrm{K}$ transforming it into $\mathrm{MK}$, a highly pozzolanic product. Under these activation conditions, the mica showed an incipient state of dehydroxylation [40]. 


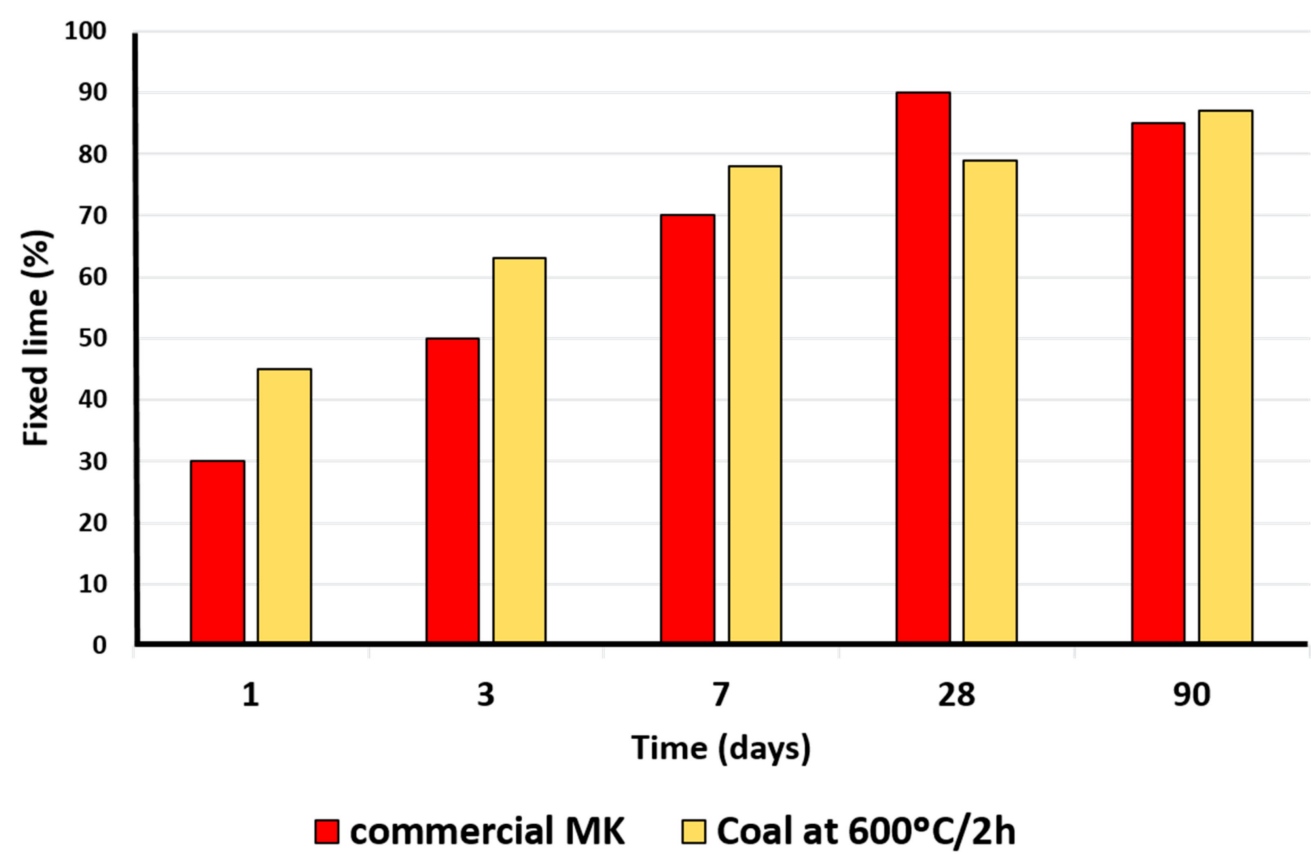

Figure 8. Fixed lime of the thermally activated coal refuse (slap heap) sample at $600{ }^{\circ} \mathrm{C} / 2 \mathrm{~h}$ from 1 to 90 days of pozzolanic reaction.

\section{Conclusions}

- Four types of coal-mining waste-very fine-grade, fine-grade, and coarse-grade coal tailings, and coal refuse-extracted from the slag heaps of abandoned coal mines near the locality of Santa Lucía, in the Spanish province of León, have been studied. From among them all, one was selected due to the presence of high volumes of waste and the facility of its use as an additional pozzolanic cement additive.

- The four samples of coal waste were thermally activated at $600{ }^{\circ} \mathrm{C}$, over two hours in an electric furnace to improve the pozzolanic properties. The selected temperature has advantages from both an economic and an energetic point of view.

- The results of XRD analysis have confirmed that all $\mathrm{K}$ is transformed into MK (a pozzolan specified in commercial cement manufacturing standards) over a heating time of 2 hours at that temperature $\left(600^{\circ} \mathrm{C} / 2 \mathrm{~h}\right)$.

- The results show that after the activation process, the coal refuse presented sufficiently good pozzolanic activity for it to be used as a pozzolanic addition in industrial cements, emphasizing the potential of this process for the removal of contaminated waste from the environment.

Acknowledgments: This research was supported by the Spanish Ministry of Economy and Competitiveness (Project Ref BIA2015-65558-C3-1-2-3R (MINECO/FEDER)). The authors are also grateful to the Sociedad Anónima Huellera Vasco-Leonesa and to the Spanish Cement Institute (IECA) for their assistance with this research.

Author Contributions: Moisés Frías and Raquel Vigil de la Villa Mencía designed the experiments; Santiago Yagüe contributed materials and performed the experiments; Isabel Sánchez and Antonio Zapardiel analyzed the data; Rosario García-Giménez wrote the paper.

Conflicts of Interest: The authors declare no conflict of interest. 


\section{References}

1. Frías, M.; Sánchez de Rojas, M.I.; Santamaría, J.; Rodríguez, C. Recycling of silicomanganese slag as a pozzolanic material in Portland cements: Basic and engineering properties. Cem. Concr. Res. 2006, 36, 487-491. [CrossRef]

2. Frías, M.; Villar-Cociña, E.; Savastano, H. Brazilian sugar bagasse ashes from the cogeneration industry as active pozzolans for cement manufacture. Cem. Concr. Comp. 2011, 33, 490-496. [CrossRef]

3. Vegas, I.; Urreta, J.; Frías, M.; García, R. Freeze-thaw resistance of blended cements containing calcined paper sludge. Constr. Build. Mater. 2009, 23, 2862-2868. [CrossRef]

4. Pereira, M.L.; Jane, S.; Tomazini, F.; Petrisin, C.; Kunihiko, P.; Vieira, A.; Leslie, R. Red mud from Brazil: Thermal behaviour and physical properties. Ind. Eng. Chem. Res. 2012, 51, 775-786.

5. Loh, Y.R.; Sujan, D.; Rahman, M.E.; Das, C.A. Sugarcane bagasse-The future composite material: A literature review. Res. Concr. Rec. 2013, 75, 14-22.

6. Ekosse, G. Provenance of the Kgwakgwe kaolin deposit in Southeastern Botswana and its possible utilization. Appl. Clay Sci. 2001, 20, 137-152. [CrossRef]

7. Frías, M. Study of Hydrated Phases Present in a MK-Lime System Cured at $60^{\circ} \mathrm{C}$ and 60 Months of Reaction. Cem. Concr. Res. 2006, 36, 827-831. [CrossRef]

8. Snelson, D.; Wild, S.; O'Farrell, M. Heat of hydration of Portland cement-MK-FA blends. Cem. Concr. Res. 2008, 38, 832-840. [CrossRef]

9. Siddique, R.; Klaus, J. Influence of metakaolin on the properties of mortar and concrete: A review. Appl. Clay Sci. 2009, 43, 392-400. [CrossRef]

10. Ríos, C.; Williams, C.; Fullen, M. Hydrothermal synthesis of hydrogarnet and tobermorite at $175^{\circ} \mathrm{C}$ from kaolinite and metakaolinite in the $\mathrm{CaO}-\mathrm{Al}_{2} \mathrm{O}_{3}-\mathrm{SiO}_{2}-\mathrm{H}_{2} \mathrm{O}$ system: A comparative study. Appl. Clay Sci. 2009, 43, 228-237. [CrossRef]

11. Frías, M.; Vigil de la Villa, R.; García, R.; Sánchez de Rojas, M.I.; Juan, A. The influence of slate waste activation conditions on mineralogical changes and pozzolanic behavior. J. Am. Cer. Soc. 2013, 96, 2276-2282. [CrossRef]

12. García-Giménez, R.; Vigil de la Villa Mencía, R.; Rubio, V.; Frías, M. The transformation of coal-mining waste minerals in pozzolanic reactions of cements. Minerals 2016, 6, 64. [CrossRef]

13. Finkelman, R.B. Potential health impacts of burning coal beds and waste banks. Int. J. Coal Geol. 2004, 51, 19-24. [CrossRef]

14. Suárez-Ruiz, I.; Crelling, J.C. Applied Coal Petrology: The Role of Petrology in Coal Utilization; Elsevier: Amsterdam, The Netherlands, 2008; p. 388.

15. Suárez-Ruiz, I.; Flores, D.; Mendonça Filho, J.G.; Hackley, P.C. Review and update of the applications of organic petrology: Part 2, geological and multidisciplinary applications. Int. J. Coal Geol. 2012, 98, 73-94. [CrossRef]

16. Ribeiro, J.; Suárez-Ruiz, I.; Flores, D. Geochemistry of self-burning coal mining residues from El Bierzo Coalfield (NW Spain): Environmental implications. Int. J. Coal Geol. 2016, 159, 155-168. [CrossRef]

17. Nádudvari, A.; Fabiańska, M.J. The impact of water-washing, biodegradation and self-heating processes on coal waste dumps in the Rybnik Industrial Region (Poland). Int. J. Coal Geol. 2016, 154-155, 286-299. [CrossRef]

18. Ribeiro, J.; Ferreira da Silva, E.; Flores, D. Burning of coal waste piles from Douro Coalfield (Portugal): Petrological, geochemical and mineralogical characterization. Int. J. Coal Geol. 2010, 81, 359-372. [CrossRef]

19. Bell, F.G.; Bullock, S.E.T.; Hälbich, T.F.J.; Lindsay, P. Environmental impacts associated with an abandoned mine in the Witbank Coalfield, South Africa. Int. J. Coal Geol. 2001, 45, 195-216. [CrossRef]

20. Younger, P.L. Environmental impacts of coal mining and associated wastes: A geochemical perspective. In Energy, Waste and the Environment: A Geochemical Perspective; Gieré, R., Stille, P., Eds.; Geological Society, Special Publications: London, UK, 2004; Volume 236, pp. 169-209.

21. Bailey, M.T.; Gandy, C.J.; Watson, I.A.; Wyatt, L.M.; Jarvis, A.P. Heat recovery potential of mine water treatment systems in Great Britain. Int. J. Coal Geol. 2016, 164, 77-84. [CrossRef]

22. Gorakhki, M.H.; Bareither, C.A. Unconfined Compressive Strength of Synthetic and Natural Mine Tailings Amended with Fly Ash and Cement. J. Geotech. Geoenviron. Eng. 2017, 143, 1-14. [CrossRef] 
23. Kesimal, A.; Yilmaz, E.; Ercikdi, B.; Alp, I.; Deveci, H. Effect of properties of tailings and binder on the short-and long-term strength and stability of cemented paste backfill. Mater. Lett. 2005, 59, 3703-3709. [CrossRef]

24. Qian, G.; Huang, T.; Bai, S. Use of cement-stabilized granite mill tailings as pavement subbase. J. Mater. Civ. Eng. 2011, 23, 1575-1578. [CrossRef]

25. Bian, Z.; Dong, J. The impact of disposal and treatment of coal mining wastes on environment and farmland. Environ. Geol. 2009, 58, 625-634. [CrossRef]

26. CEDEX. Monografía sobre Catálogo de Residuos Utilizables en la Construcción; Ficha Técnica; CEDEX: Madrid, Spain, 2007.

27. Hernández-Mendoza, H.; Mejuto, M.; Cardona, A.I.; García-Álvarez, A.; Millán, R.; Yllera, A. Optimization and validation of a method for heavy metals quantification in soil samples by inductively coupled plasma sector field mass spectrometry (ICP-SFMS). Am. J. Anal. Chem. 2013, 4, 9-15. [CrossRef]

28. Chen, X.D. On the fundamentals of diffusive self-heating in water containing combustible materials. Chem. Eng. Process. 1998, 37, 367-378. [CrossRef]

29. Garcia, P.; Hall, P.J.; Mondragon, F. The use of differential scanning calorimetry to identify coals susceptible to spontaneous combustion. Thermochim. Acta 1999, 336, 41-46. [CrossRef]

30. Lyman, R.; Volkmer, J. Pyrophoricity (Spontaneous Combustion) of Powder River Basin Coals_Considerations for Coalbed Methane Development; Coal Report CR01; Wyoming State Geological Survey: Laramie, WY, USA, 2001.

31. Kaymakci, E.; Didari, V. Relations between coal properties and spontaneous combustion parameters. Turk. J. Eng. Environ. Sci. 2002, 26, 59-64.

32. Lohrer, C.; Schmidt, M.; Krause, U. Influence of environmental parameters on the self-ignition behavior of coal. In Proceedings of the International Conference on Coal Fire Research, Beijing, China, 29 November-1 December 2005.

33. Ribeiro, J.; Suárez-Ruiz, I.; Ward, C.R.; Flores, D. Petrography and mineralogy of self-burning coal wastes from anthracite mining in the El Bierzo Coalfield (NW Spain). Int. J. Coal Geol. 2016, 154, 92-106. [CrossRef]

34. Moore, D.M.; Reynolds, R.C. X-ray Diffraction and the Identification and Analysis of Clay Minerals, 2nd ed.; Oxford University Press: New York, NY, USA, 1987.

35. Renaudin, G.; Russias, J.; Leroux, F.; Frizon, F. Structural characterization of C-S-H and C-A-S-H samples-Part I: Long-range order investigated by Rietveld analyses. J. Solid State Chem. 2009, 182, 3312-3319. [CrossRef]

36. Stephan, D.; Maleki, H.; Knofel, D.; Eber, B.; Hardtl, R. Influence of Cr, Ni, Zn on the properties of pure clinker phases. Part I. C3S. Cem. Concr. Res. 1999, 29, 545-552. [CrossRef]

37. Ambroise, J.; Murat, M.; Pera, J. Investigations on Synthetic Binders Obtained by Middle-Temperature Thermal Dissociation of Clay Minerals. Silic. Ind. 1986, 7, 99-107.

38. Vigil de la Villa, R.; Frías, M.; García-Giménez, R.; Martínez Ramírez, S.; Fernández-Carrasco, L. Chemical and mineral transformations that occur in mine waste and washery rejects during pre-utilization calcination. Int. J. Coal Geol. 2014, 132, 123-130. [CrossRef]

39. Frías, M.; Cabrera, J. Influence of MK on the reaction kinetics in MK/lime and MK blended cement systems at $20{ }^{\circ}$ C. Cem. Concr. Res. 2001, 31, 519-527. [CrossRef]

40. Sayanam, R.A.; Kalsotra, A.K.; Mehta, S.K.; Singh, R.S.; Mandal, G. Studies on thermal transformations and pozzolanic activities of clay from Jammu region (India). J. Therm. Anal. 1989, 35, 99-106. [CrossRef]

(C) 2018 by the authors. Licensee MDPI, Basel, Switzerland. This article is an open access article distributed under the terms and conditions of the Creative Commons Attribution (CC BY) license (http://creativecommons.org/licenses/by/4.0/). 